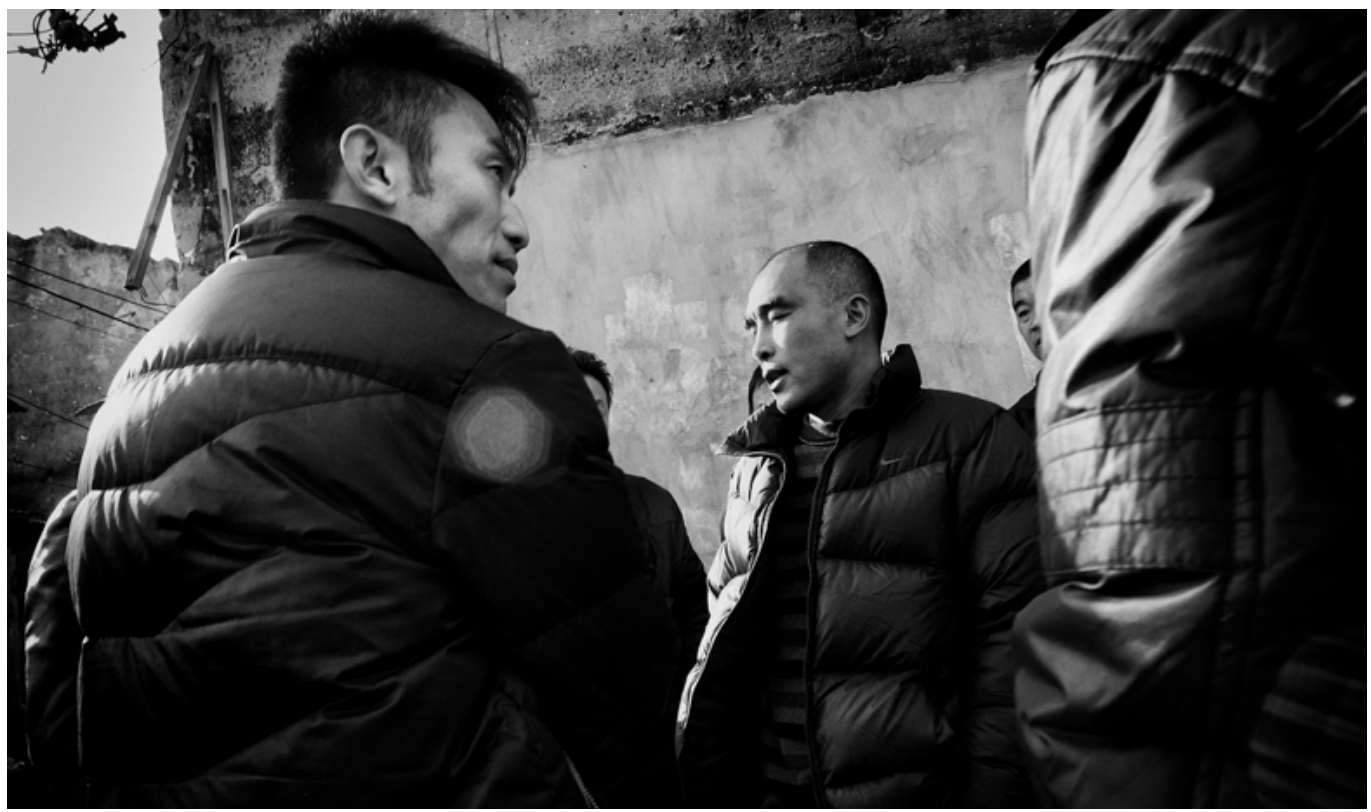

\section{Outsourcing Coercion and Social Control}

Lynette H. ONG

To carry out coercion and social control, the Chinese government often resorts to non-state actors, including thugs-for-hire, profit-seeking brokers, and even commercial enterprises. In this essay, Lynette Ong examines the circumstances under which the authorities use these means and the reasons behind their choices, arguing that this is mostly related to the need of reducing the cost of repression and evading responsibility.
'Thugs' Shanghai

(2012). PC: Rob-

Shanghai@flickr.com.

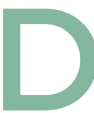

uring the Occupy Movement in Hong Kong in 2014, protestors were reportedly beaten up by unidentified thugs from neighbouring Guangdong province in China (Lim 2014). In 2012, local authorities hired scores of thugs to lock up the blind activist Chen Guangcheng in order to keep him out of the public eye (Branigan 2012). Local governments also work with professional intermediaries to convince aggrieved citizens to give up their resistance against the state, and engage private security personnel to intercept petitioners heading to Beijing (Wen 2017).

Why does the Chinese government-which is known for its strong-arm tactics-need or desire to use non-state actors to carry out coercion and social control? In this essay, I argue the government seeks to deploy non-state actors 
to perform coercive acts or exercise social control for a wide range of reasons, such as reducing the cost of repression and evading responsibility. These non-state actors range from thugs-for-hire, to profit-seeking brokers and even commercial enterprises (Ong 2018 and 2019).

\section{Thugs-for-Hire}

The government is most likely to use thugsfor-hire when it is carrying out illegal actions or unpopular policies, such as collecting unlawful exactions, evicting farmers and homeowners from their properties, or intimidating petitioners and dissidents. The third-party nature of these actors makes them expedient for carrying out illegal and unpopular policy implementation when formal uniformed agents, such as the police, could not be sent without harming state legitimacy.

The government is also likely to hire thugs when it seeks to evade accountability for its own actions. More often than not, this is related to the use of illegitimate violence to crack down on citizens. To the extent that the government does not want to be seen as using illegitimate force, it is likely to outsource violence to third parties. The thugs' elusive identity allows the government to maintain an arms-length relationship with them and the violent acts they commit.

In China, thugs are most likely to be hired to evict farmers and homeowners from their properties, and to intimidate protestors and dissidents into giving up their actions against the state. Because these state actions are unpopular, if not outright illegal, local governments are very reluctant to deploy formal coercive agents to carry out the work. Thugs, who are hired on a project basis, also help local governments that are weak in fiscal and coercive capacity to carry out centralmandated policies, such as land expropriation, housing demolition, and maintaining social stability by minimising dissent. Thugs-for-hire could be seen as contractual workers, who can be hired and terminated easily, unlike formal agents on government payroll (bianzhi) who enjoy a range of work benefits.

\section{Agency Problems}

Yet, outsourcing violence is often subject to agency problems. The government cannot exert tight control over these agents' actions. When thugs are sent to intimidate residents and demolish houses, excessive violence is often used, which can result in casualties. When local governments hire private security personnel to intercept petitioners, it is common for these private agents to abuse their power against vulnerable citizens seeking help. When municipal authorities employ illtrained chengguan, some of whom are local ruffians, violence against marginal unlicensed street vendors becomes rampant. Effective and efficient as these coercive measures may be, agent-centred excessive violence often serves to attract sympathisers, which in turn mobilises support for resistance, rather than deterring it.

Violent agents may start off as thugs-for-hire on government projects for local authorities. However, over time they can evolve into mafia groups running vices such as gambling and prostitution rings. Some local authorities in China have grown so reliant on local mafia groups that their own power has been usurped. While it is challenging to estimate the scale or degree of this problem, we know for certain that the nexus between local governments and local mafia groups has become grave enough to warrant the Xi Jinping administration's launch of a massive campaign to fight against local organised crime (Shi 2018).

China is by no means the only country that hires violent agents to do dirty job. The United States government contracted out abuse of prisoners in Abu Ghraib to the security company Blackwater. During the Arab Spring protests, the Mubarak and Assad regimes also 
mobilised thugs-the 'Baltagiya' in Egypt and 'Shahiba' in Syria-to violently attack prodemocracy protestors (Batal al-Shishani and Elsheikh 2012).

\section{Huangniu}

In my research on housing demolition (fangwu zhengshou), I write about how the Chinese state also works with profit-seeking middlemen who can help establish trust between officials and citizens to resolve conflicts (Ong 2019). These brokers bring together the state and aggrieved citizens to facilitate state-society bargaining that would not have taken place otherwise. This bargaining may result in payouts or under-the-table deals, which help to resolve protracted stand-offs that might have otherwise spilled over into street protests.

In housing demolition projects in Chinese cities, municipal and local governments not only face tight deadlines, but are also under intense pressure to contain social contention. These two priorities can often be conflicting in nature. When a date for demolition is set, all households in the designated area must vacate by the agreed-upon deadline. Lack of compliance from one or two households can potentially put the entire project in jeopardy, necessitating severe tactics on the part of local governments and property developers. At the same time, however, preventing and repressing popular protests by aggrieved residents being quickly pushed out of their family homes is also a priority of municipal and local governments.

Local governments have limited options in dealing with this dilemma. Even though violence, such as hiring thugs, is often the most efficient means to evict residents, local officials are increasingly constrained in deploying coercive force against recalcitrant urban households. Increased media scrutiny and greater educational attainment of urban dwellers have given rise to a growing rights awareness, especially in major cities across the country. When the state is restrained in using violence but faces strong pressures to complete projects on time, it becomes more receptive to bargaining with citizens. The demand for brokers capable of facilitating a deal has therefore increased.

'Almost Gone,

Shanghai (2012)

PC: Rob-Shanghai

@flickr.com.

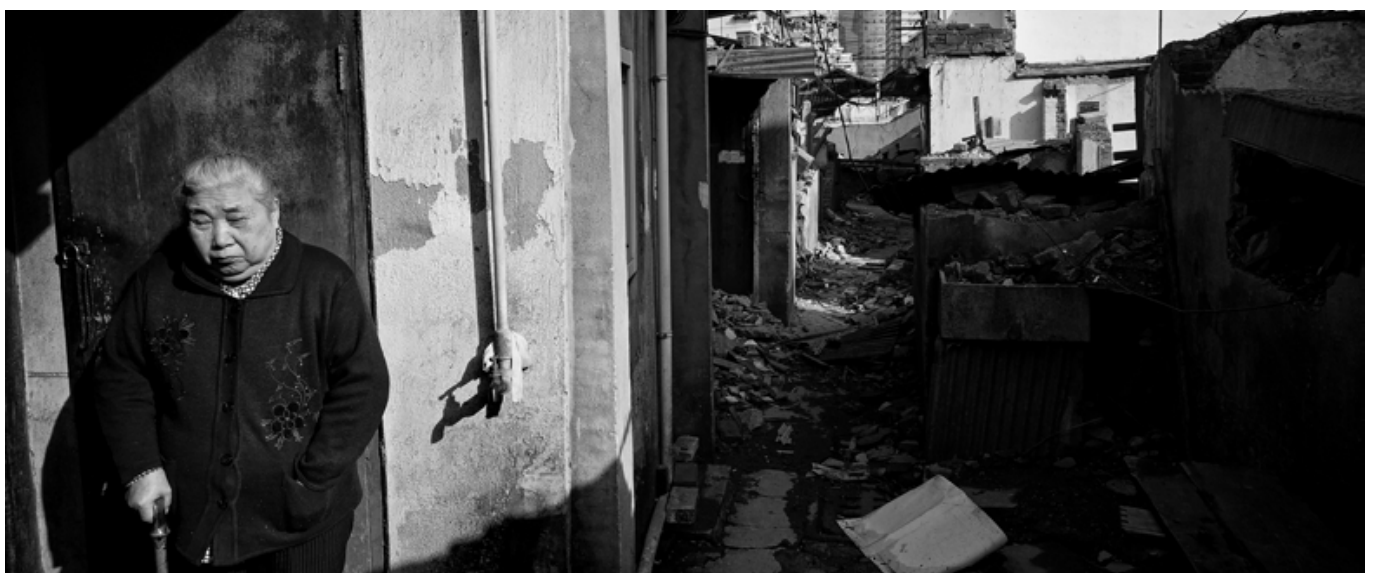


These brokers are called huangniu in Chinese-a generally pejorative term that literally means 'cattle', but is used to describe middlemen who provide highly sought-after goods or services at prices above market value. In the context of housing demolition, these brokers are usually hired by disgruntled citizens to bargain with the state for better deals. In general, state officials willingly work with huangniu in order to forge agreements with society. The intermediary role of these professionals is enabled by the trust they have established with both the citizens and local officials. The extra payouts that are attributable to intermediary efforts, in terms of extra financial payout or apartment units, are then split between the citizen-client and the huangniu.

\section{A Commodification of State-Society Bargaining}

These profit-seeking brokers represent a commodification of state-society bargaining by matching demands from discontented citizens with the supply of special favours by state officials. In so doing, a commercialand technically illegal-deal is secured that involves a compensation over and above that mandated by official policy, or what other citizens in a similar position who do not engage an intermediary are entitled to.

Brokers who collude with insidergovernment agents help clients to secure favourable treatment. In contexts outside of housing demolition, under-the-table payments are made to corrupt intermediaries who issue drivers' licenses that may otherwise take them a few rounds of tests to obtain. Routine traffic offenders pay a huangniu with connections in the transport authority to wipe their records of traffic offences. Similarly, huangniu are utilised by truck drivers seeking exemptions from inspections, companies that need registration but do not meet the requirements, and taxpayers who want to pay lower taxes.
These examples, and many more, underline the wider implication of intermediated illegal transactions-the widespread abuse of state power bestowed upon government agents.

Corrupt brokers are in a unique position to bring together the state and citizens who are unable to reach demolition agreements. On the one hand, they have intimate connections with government agents that make them privy to insider information about government policies or the decisions of local officials unbeknown to citizens. On the other hand, they are able to gain the trust of clients, either because they are part of their networks or because they publicise their close connections with government agents. The huangniu promise their clients compensation higher than that mandated by official policy and, more often than not, they are able to deliver. In addition, huangniu provide related services essential for securing higher compensation. These include producing fake marriage and divorce certificates, bogus proof of pregnancy, and other similar documents to inflate the number of household members to be resettled. These services accentuate the illegality of the transactions and the role of corrupt intermediaries in housing demolition. But, they also increase their clients' entitlements to higher compensation.

The case of huangniu in housing demolition highlights the state's willingness and ability to engage with market agents who can help to fulfil state's objectives in exchange for profit. Together with thugs-for-hire, the existence of these kinds of intermediaries underscores the Chinese state's adroit use of non-state or market agents to preempt, absorb, and repress social contention and protests, when state actors cannot do it efficiently or effectively. 
This text is taken from Dog Days: A Year of Chinese Labour, Civil Society, and Rights, Made in China Yearbook 2018, edited by Ivan Franceschini and Nicholas Loubere, published 2019 by ANU Press, The Australian National University, Canberra, Australia.

doi.org/10.22459/MIC.04.2019.25 